\title{
Anti-oxidation and Anti-wrinkling Effects of Jeju Horse Leg Bone Hydrolysates
}

\author{
Dongwook Kim, Hee-Jin Kim, Hyun-Seok Chae', Nam-Gun Park', Young-Boong Kim², and Aera Jang* \\ Department of Animal Products and Food Science, Kangwon National University, Chuncheon 200-701, Korea \\ ${ }^{1}$ National Institute of Animal Science, RDA, Jeju 690-150, Korea \\ ${ }^{2}$ Korea Food Research Institute, Sungnam 463-746, Korea
}

\begin{abstract}
s
This study focused on the anti-oxidative and collagenase- and elastase inhibition effects of low molecular weight peptides (LMP) from commercial Jeju horse leg bone hydrolysates (JHLB) on pancreatin, via enzymatic hydrolysis. Cell viability of dermal fibroblasts exposed to UVB radiation upon treatment with LMP from JHLB was evaluated. Determination of the antioxidant activity of various concentrations of LMP from JHLB were carried out by assessing 1,1-diphenyl-2-picrylhydrazyl (DPPH) and 2,2-azino-bis-3-ethybenzothiazoline-6-sulphonic acid (ABTS) radical scavenging activity, ferric reducing antioxidant power (FRAP), and oxygen radical absorbance capacity (ORAC). The DPPH radical scavenging activity of LMP from JHLB $(20 \mathrm{mg} / \mathrm{mL})$ was $92.21 \%$ and ABTS radical scavenging activity $(15 \mathrm{mg} / \mathrm{mL})$ was $99.50 \%$. FRAP activity $(30 \mathrm{mg} / \mathrm{mL})$ was $364.72 \mu \mathrm{M} / \mathrm{TE}$ and ORAC activity $(1 \mathrm{mg} / \mathrm{mL})$ was $101.85 \mu \mathrm{M} / \mathrm{TE}$. The anti-wrinkle potential was assessed by evaluating the elastase- and collagenase inhibition potential of these LMP. We found that $200 \mathrm{mg} / \mathrm{mL}$ of LMP from JHLB inhibited elastase activity by $41.32 \%$, and $100 \mathrm{mg} / \mathrm{mL}$ of LMP from JHLB inhibited collagenase activity by $91.32 \%$. The cell viability of untreated HS68 human dermal fibroblasts was $45 \%$ when exposed to a UVB radiation dose of $100 \mathrm{~mJ} / \mathrm{cm}^{2}$. After $24 \mathrm{~h}$ of incubation with $500 \mu \mathrm{g} / \mathrm{mL}$ LMP from JHLB, the cell viability increased to $60 \%$. These results indicate that LMP from JHLB has potential utility as an anti-oxidant and anti-wrinkle agent in the food and cosmetic industry. Additional in vivo tests should be carried out to further characterize these potential benefits.
\end{abstract}

Keywords: horse leg bone, hydrolysates, collagenase, elastase, anti-oxidation

\section{Introduction}

Aging of the skin is a process that involves intrinsic (chronologic) aging and extrinsic aging, which is caused by stresses such as UV light exposure. Exposure of skin to UV light leads to progressive loss of structural integrity and physiological function (Farage et al., 2008). Human skin is constantly being exposed to environmental irritants, and this can lead to the production of free radicals and reactive oxygen species that cause serious damage to the skin cells. Intracellular and extracellular oxidative stress initiated by reactive oxygen species (ROS) accelerates skin aging, which is characterized by wrinkle formation and atypical pigmentation (Masaki, 2010). These changes are induced by alterations in dermal connective tissues such as collagen, elastin fibrillin, and pro-

*Corresponding author: Aera Jang, Department of Animal Products and Food Science, Kangwon National University, Chuncheon 200-701, Korea. Tel: +82-33-250-8643, Fax: +82-33-2595574, E-mail: ajang@kangwon.ac.kr teoglycans (Jeon et al., 2013; Uitto and Bernstein, 1998). Considerable research efforts in the cosmetic industry have focused on the mechanisms by which the symptoms of skin aging can be delayed or improved (Cheon et al., 2008). The use of certain natural products for protecting against skin aging has recently been proposed; these include ginseng, aloe vera, berries, and porcine placenta (Han et al., 2013).

Bone broth has been consumed for ages as an important source of nutrients. It is used as a traditional folk medicine across cultures for the sick and weak, especially for ailments affecting connective tissues such as the gastrointestinal tract, joints, skin, lungs, muscle, and blood (Siebecker, 2005). Most Asians enjoy consuming bone broth, especially, Koreans, who like to have Hanwoo (Korean native cattle) bone broth in winter for nourishment. Bone primarily contains collagen, a key building block of cells for bones, cartilage, ligaments, and the brain. In addition, the bone marrow may positively affect the immune system because it helps in the transport of oxygen to the body cells. The marrow contains essential 
minerals such as $\mathrm{Ca}, \mathrm{Fe}$, and $\mathrm{P}$, which are necessary for maintaining healthy bones. Kim et al. (2007) studied the effect of maturity score and extraction numbers on collagen, protein, and chondroitin sulfate content from the Hanwoo shank bone. They found that collagen and protein content was the highest in water extracts from Hanwoo shank bones with a maturity score of 2 (young bulls and steers), and the chondroitin sulfate content significantly decreased with an increase in the number of extractions.

Equine bone and bone extracts from Juju island in Korea are being extensively distributed owing to their bioactive function. One of the health benefits of these equine bone extracts is that they cause an increase in bone density and improve bone health. A study found that dietary supplementation with horse leg bone water extracts for 8 weeks significantly increases the uterine/body weight ratio and bone mineral density of female rats with postmenopausal osteoporosis (Park et al., 2010). In our previous study, a large antioxidant effect was observed in the low molecular weight peptide fraction of less than 3 $\mathrm{kDa}$ isolated from leg bone extracts via enzyme hydrolysis (Kim et al., 2013). However, there is still a lack of scientific information about the anti-oxidant and anti-wrinkle activities of enzyme hydrolysates from horse leg bone extracts. This study aimed to evaluate the characteristics of horse leg bone hydrolysates generated by pancreatin treatment on anti-oxidant activity as well as inhibition of collagenase and elastase, which are some of the key causes of skin aging.

\section{Materials and Methods}

\section{Horse leg bone hydrolysates}

Commercial horse leg bones were obtained from an online supplier. After removing all visible impurities and debris, leg bones were washed three times with water, which was subsequently discarded. The extraction process was carried out by adding water to the bones at a ratio of 6:1 (v:v) and allowed to proceed for $8 \mathrm{~h}$ and repeated twice to produce gelatin. The extracted liquid was freezedried and the fat was removed by Folch's method and freeze-dried. Hydrolysis for $4 \mathrm{~h}$ was performed by the addition of $0.1 \%$ pancreatin (Bision Co., Korea) after reconstitution of the freeze-dried extracts in distilled water. Hydrolysates were then subjected to centrifugal filtration (Amicon ${ }^{\circledR}$ Ultra-15 centrifugal filter units, USA) to separate low molecular weight $(<3 \mathrm{kDa})$ hydrolysate fractions. The filtered hydrolysates (JHLB) were collected and lyo- philized for use in subsequent experiments.

\section{Cell culture}

The normal human newborn foreskin fibroblast cell line, HS68 (ATCC CRL 1635), was purchased from the American Type Culture Collection (ATCC, USA). HS 68 cells were plated in 100-mm tissue culture dishes containing Dulbecco's modified Eagle's medium (DMEM) supplemented with $10 \%$ fetal bovine serum (FBS) and 1\% penicillin/streptomycin (Gibco, USA). HS 68 cells were incubated at $37^{\circ} \mathrm{C}$ with $5 \% \mathrm{CO}_{2}$ gas in a humidified incubator.

\section{Ultraviolet irradiation and cell cytotoxicity}

HS 68 cells were seeded on 48-well tissue culture plates at a density of $10^{5}$ cells $/ \mathrm{mL}$ in DMEM containing $10 \%$ FBS with $1 \%$ penicillin/streptomycin and incubated for $24 \mathrm{~h}$. Thereafter, the DMEM was discarded and the cell wells washed with phosphate-buffered saline (PBS). Next, $500 \mu \mathrm{L}$ of PBS and various concentrations of hydrolysate samples were added to the cell wells and the HS 68 cells were exposed to UVB radiation at dose of $100 \mathrm{~mJ} / \mathrm{cm}^{2}$. After irradiation, cells were treated with hydrolysate samples and incubated for another $24 \mathrm{~h}$, following which 0.05 $\mathrm{mg} / \mathrm{mL}$ of 3-(4,5-dimethylthiazol-2-yl)-2,5-diphenyltetrazolium bromide (MTT) was added to each well. The wells were then incubated for $4 \mathrm{~h}$ at $30^{\circ} \mathrm{C}$. The medium was discarded and the MTT formazan produced was extracted by addition of $200 \mu \mathrm{L}$ of DMSO/well. Cell viability was by measuring absorbance at $560 \mathrm{~nm}$ for each well (SpectraMax M2e, Molecular Devices, USA). Media blanks and untreated control groups were also measured.

\section{Antioxidant effect}

\section{1,1-Diphenyl-2-picrylhydrazyl (DPPH) radical sca-} venging activity

DPPH radical scavenging activity of an aqueous solution of JHLB was estimated according to the method of Blois (1958) with slight modification. In brief, $200 \mu \mathrm{L}$ of a $1 \%$ aqueous hydrolysate solution was added to $800 \mu \mathrm{L}$ of water and $1 \mathrm{~mL}$ of methanolic DPPH solution $(0.2$ $\mathrm{mM})$. The mixture was vortexed and left to stand at room temperature for $30 \mathrm{~min}$. A tube containing $1 \mathrm{~mL}$ of distilled water and $1 \mathrm{~mL}$ of methanolic DPPH solution $(0.2$ $\mathrm{mM}$ ) served as the control. The absorbance of the solution was measured spectrophotometrically at $517 \mathrm{~nm}$ (SpectraMax M2e, Molecular Devices, USA). Vitamin C $(1 \mathrm{mg} / \mathrm{mL})$ was used as a positive control to compare the 
antioxidant activity of the hydrolysate samples. The percentage of DPPH radical scavenging was determined using the following equation:

$$
\begin{aligned}
& \text { DPPH radical scavenging activity (\%) } \\
& \quad 1-\frac{(\text { sample O.D. }- \text { reference O.D. })}{(\text { control O.D. })} \times 100 \\
& \quad * \text { Control }=1 \mathrm{~mL} \mathrm{DW}+1 \mathrm{~mL} 0.2 \mathrm{mM} \text { DPPH solution } \\
& \text { in } \mathrm{MeOHG} \\
& \quad * \text { Reference }=1 \mathrm{~mL} \mathrm{DW}+1 \mathrm{~mL} \mathrm{MeOH}
\end{aligned}
$$

2,2'-Azino-bis-3-ethybenzothiazoline-6-sulphonic acid (ABTS) radical scavenging activity

ABTS radical scavenging activity of JHLB was determined following the adapted Trolox-equivalent antioxidant capacity (TEAC) assay as described by Re et al. (1999). ABTS radical cation $\left(\mathrm{ABTS}^{+}\right)$was produced by reacting $14 \mathrm{mM}$ ABTS with an equal volume of $4.9 \mathrm{mM}$ potassium persulfate (final concentration: $7 \mathrm{mM}$ ABTS in $2.45 \mathrm{mM}$ potassium persulfate). The mixture was incubated in the dark at room temperature for 12-16 $\mathrm{h}$ before use. The $\mathrm{ABTS}^{+}$solution was diluted with $5.5 \mathrm{mM}$ PBS (pH 7.4) to an absorbance of $0.70 \pm 0.02$ at $734 \mathrm{~nm}$ (SpectraMax M2e, Molecular Devices, USA) and equilibrated at $30^{\circ} \mathrm{C}$. An aliquot $(50 \mu \mathrm{L})$ of hydrolysate was prepared as described for DPPH or Trolox standards (0, 0.3, 0.7, 0.9 , and $1.2 \mathrm{mM}$ in PBS; Fluka Chemie GmbH, Switzerland) and added to $950 \mathrm{iL}$ of the diluted ABTS+ solution; the absorbance was read (SpectraMax M2e, Molecular Devices, USA) at $30^{\circ} \mathrm{C} 1 \mathrm{~min}$ after the initial mix and up to $6 \mathrm{~min}$ thereafter. Vitamin $\mathrm{C}(1 \mathrm{mg} / \mathrm{mL})$ was used as a positive control to compare the anti-oxidative activity of samples. The ABTS radical scavenging activity was calculated using the following formula:

$$
\begin{aligned}
& \text { DPPH radical scavenging activity }(\%) \\
& =\frac{(\text { control O.D. }- \text { sample O.D. })}{\text { (control O.D.) }} \times 100
\end{aligned}
$$

${ }^{*}$ Control O.D. $=0.70$ at $734 \mathrm{~nm}$

\section{Ferric reducing antioxidant power (FRAP) assay}

FRAP assay was determined by the method described by Benzie and Strain (1996) with slight modification. Briefly, the FRAP reagent was prepared fresh for each analysis with $300 \mathrm{mM} / \mathrm{L}$ acetate buffer, $10 \mathrm{mM} \mathrm{2,4,6-tripy-}$ ridyl-s-triazine (TPTZ) solution, and $20 \mathrm{mM}$ ferric chloride solution at the ratio of 10:1:1 (v/v), respectively. Hydrolysate samples $(25 \mu \mathrm{L})$ were aliquoted in test tubes and FRAP reagent $(175 \mu \mathrm{L})$ was added before measuring the absorbance at $595 \mathrm{~nm}$. A standard curve was established using Trolox solution $(0,10,30,50,70$, and 100 $\mu \mathrm{M})$ and FRAP calculated as millimolar Trolox equivalents per gram.

\section{Oxygen radical absorbance capacity (ORAC) as- say}

The ORAC assay was carried out by following the method described by Gillespie et al. (2007) with slight modification. The reaction was performed in PBS (75 $\mathrm{mM}, \mathrm{pH} 7.0$ ) in a 96 well plate and each well contained a final volume of $200 \mu \mathrm{L}$ solution consisting of $150 \mu \mathrm{L}$ of fluorescein $(80 \mathrm{nM})$ and $25 \mu \mathrm{L}$ of hydrolysate sample. The reaction solution was preincubated for $15 \mathrm{~min}$ at $37^{\circ} \mathrm{C}$ and then $25 \mu \mathrm{L}$ of AAPH $(150 \mathrm{mM})$ was added. The plate was shaken automatically for $3 \mathrm{~s}$ and fluorescence was determined at $1 \mathrm{~min}$ intervals for $60 \mathrm{~min}$ with emission and excitation wavelengths of 485 and $520 \mathrm{~nm}$, respectively, using a microplate fluorescence reader (SpectraMax M2e, Molecular Devices, USA) that was maintained at $37^{\circ} \mathrm{C}$. A blank sample and six calibration solutions of Trolox $(0,5,10,30,50,70$, and $100 \mu \mathrm{M})$ were tested. The ORAC values were calculated as area under the curve and expressed as millimolar Trolox equivalent per gram of low molecular weight JHLB.

\section{Anti-wrinkle effect}

\section{Elastase inhibitory assay}

Elastase inhibitory activity was determined by the method of Cannell et al. (1988). Briefly, the hydrolysate sample $(100 \mu \mathrm{L})$ was mixed with $120 \mu \mathrm{L}$ of $0.2 \mathrm{M}$ Tris-Cl buffer (pH 8.0) and added $20 \mu \mathrm{L}$ of $1.0 \mathrm{mM} \mathrm{N}$-succinyl-(LAla)3-p-nitroanilide. It was incubated at $20^{\circ} \mathrm{C}$ for $10 \mathrm{~min}$ and $20 \mu \mathrm{L}$ of porcine pancreas elastase (PPE) was added. It was incubated again at $5^{\circ} \mathrm{C}$ for $20 \mathrm{~min}$ and placed in cold water to stop the reaction. The absorbance was determined by spectrophotometer (SpectraMax M2e, Molecular Devices, USA) at an absorbance of $405 \mathrm{~nm}$ and inhibition activity was calculated with following equation.

$$
\begin{aligned}
& \text { Elastase inhibition activity } \\
& =\left\{1-\frac{\text { (sample O.D. }- \text { blank O.D. })}{\text { con O.D. }}\right\} \times 100
\end{aligned}
$$

\section{Collagenase inhibitory assay}

Collagenase inhibitory activity was determined by the method of Wûnsch and Heidrich (1963) with slight modification. For the reaction, $4 \mathrm{mM} \mathrm{CaCl}_{2}$ was added to 0.1 
$\mathrm{M}$ Tris- $\mathrm{HCl}$ buffer ( $\mathrm{pH}$ 7.5) and 4-phenylazobenzyloxycarbonyl-Pro-Leu-Gly-Pro-Arg $(0.3 \mathrm{mg} / \mathrm{mL})$. Next, $0.1 \mathrm{~mL}$ of hydrolysate sample was mixed with $0.25 \mathrm{~mL}$ of the solvent described above. $0.15 \mathrm{~mL}$ of collagenase $(0.2 \mathrm{mg} / \mathrm{mL})$ was added and incubated for 20 minutes at room temperature. $0.5 \mathrm{~mL}$ of $6 \%$ citric acid was added to stop the reaction then $1.5 \mathrm{~mL}$ ethylacetate was added. The supernatant was removed and the O.D. was determined by spectrophotometer (SpectraMax M2e, Molecular Devices, USA) at an absorbance of $320 \mathrm{~nm}$. Collagenase inhibition activity was determined using the following equation.

Collagenase inhibition activity

$=\left\{1-\frac{\text { (sample O.D. }- \text { blank O.D. })}{\text { con O.D. }}\right\} \times 100$

\section{Statistical analysis}

All data collected were subjected to one-way analysis of variance (ANOVA) according to the general linear model procedures for SAS software (ver. 9.SAS Institute Inc., USA). Mean values and standard error of the sample were reported. When analysis of variance indicated a significant treatment effect, Duncan's multiple range test was used to compare the mean values, and a $p$-value $<0.05$ was considered statistically significant.

\section{Results and Discussion}

\section{Antioxidant effect of LMP from JHLB}

Many methods have been used to evaluate the antioxidant activity or capacity of food compounds. These methods have been classified according to the mechanism of radical deactivation involved (hydrogen atom transfer, ORAC, or electron transfer, TEAC and DPPH), and the physiological relevance of the free radical, or according to the competitive or direct approach of the antioxidant reaction (Alvarez-Suarez et al., 2012; Prior et al., 2005). For these reasons the total antioxidant capacity of low molecular weight hydrolysates from JHLB were analyzed by these four methods based on their different radical scavenging principles (DPPH, ABTS, FRAP, and ORAC assay) and because these assays are widely used as screening methods for determining the total antioxidant capacity of foods and beverages (Alvarez-Suarez et al., 2012).

The DPPH radical scavenging activity of LMP-JHLB with various concentrations is shown in Fig. 2. Vitamin C was used as a positive control for comparison of the DPPH radical scavenging activity of LMP from JHLB. As shown, the DPPH radicals were significantly scavenged by LMP

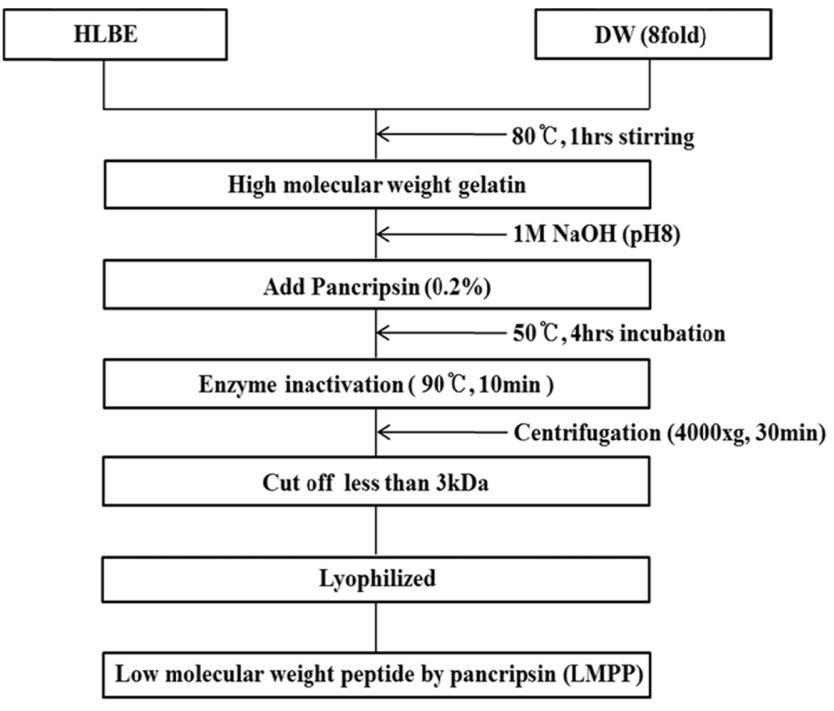

Fig. 1. Preparation procedure of LMP from JHLB extracts hydrolyzed by pancreatin.

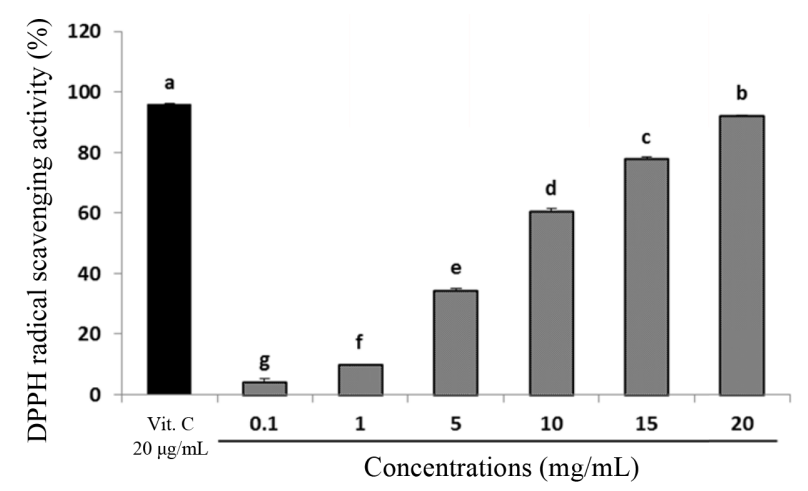

Fig. 2. DPPH radical scavenging activity (\%) of LMP from JHLB extracts hydrolyzed by pancreatin.

from JHLB in a dose dependent fashion $(p<0.05)$. In our previous study, low molecular weight (less than $3 \mathrm{kDa}$ ) peptides from Jeju horse showed higher DPPH radical scavenging activity than hydrolysates over $3 \mathrm{kDa}$ (Kim et al., 2013). The ABTS radical scavenging activity of LMP from JHLB is shown in Fig. 3. LMP from JHLB significantly reduced ABTS radicals in a dose dependent manner at concentrations ranging from 0.1 to $15 \mathrm{mg} / \mathrm{mL} .15$ and $20 \mathrm{mg} / \mathrm{mL}$ of LMP from JHLB also had ABTS radical scavenging effects that are equivalent to $100 \mu \mathrm{g} / \mathrm{mL}$ of vitamin C. Similarly, Kim et al. (2013) reported that Jeju horse hydrolysates (less than $3 \mathrm{kDa}$ ) generated by pepsin and pancreatin hydrolysis showed $0.48 \mathrm{mM}$ TE of ABTS radical scavenging activity.

The initial antioxidant value of the low molecular weight peptides $(0.1 \mathrm{mg} / \mathrm{mL})$ was $9.46 \mu \mathrm{M}$ TE whereas the 


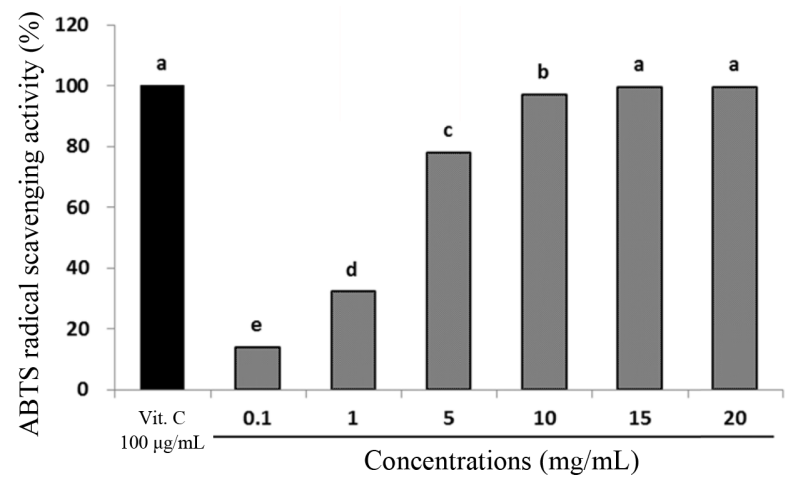

Fig. 3. ABTS radical scavenging activity (\%) of LMP from JHLB extracts hydrolyzed by pancreatin.

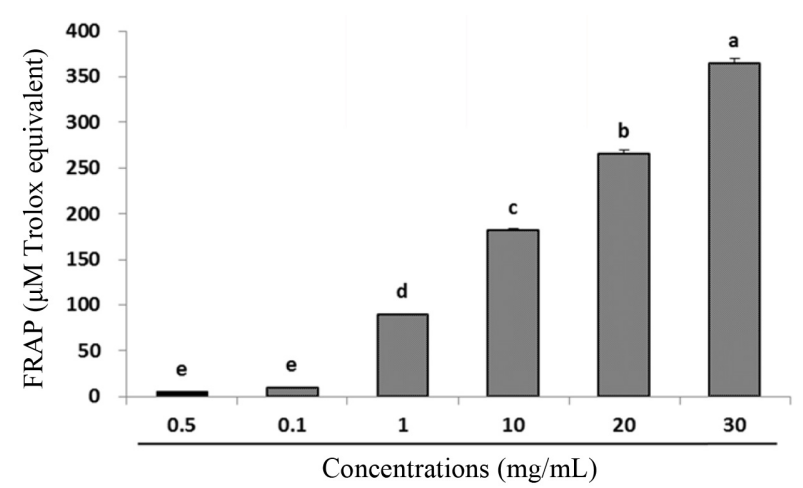

Fig. 4. Ferric reducing antioxidant power of LMP from Jeju JHLB extracts hydrolyzed by pancreatin.

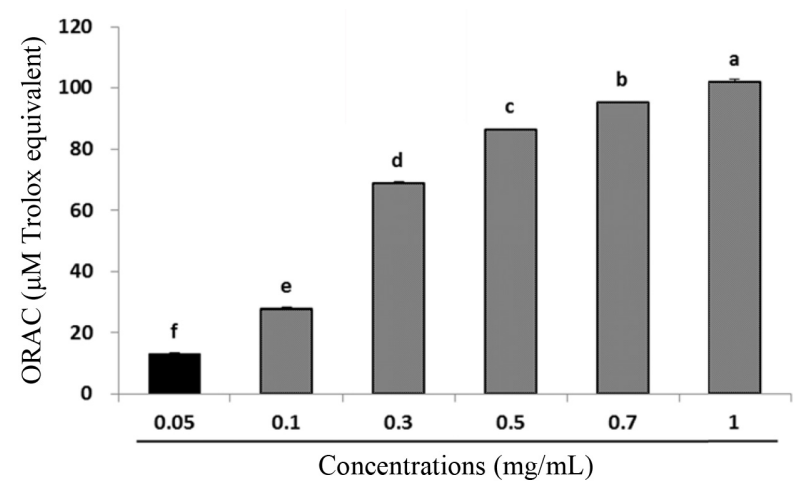

Fig. 5. Oxygen radical absorbance capacity of LMP from JHLB by pancreatin.

FRAP value of the peptides at $1,10,20$, and $30 \mathrm{mg} / \mathrm{mL}$ was $90.41,181.59,266.11$, and $364.72 \mu \mathrm{M}$ TE, demonstrating a significant increase in antioxidant activity that was dose dependent (Fig. 4). The FRAP analysis indicated a similar overall trend as was observed for the DPPH assay. The ORAC assay measures the ability of an antioxidant

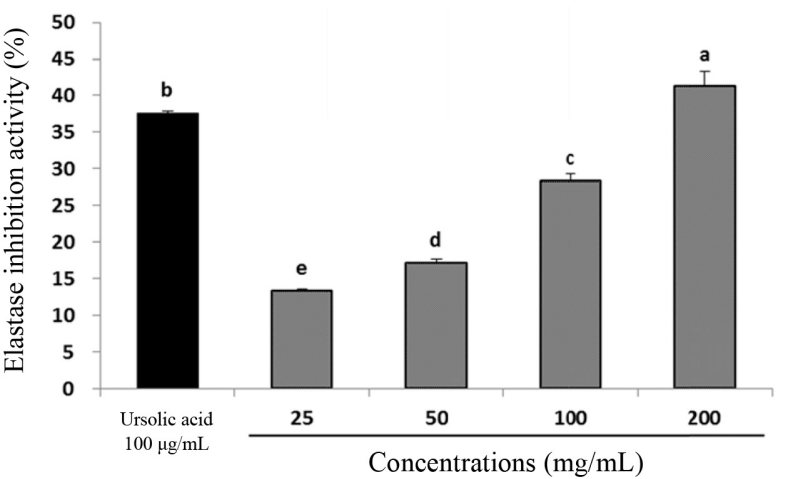

Fig. 6. Elastase inhibition activity (\%) of LMP from JHLB extracts hydrolyzed by pancreatin.

to quench free radicals by hydrogen donation, and is thus a measure of both general and specific antioxidant actions by using a fluorescent probe and monitoring the change in its fluorescence intensity (Cao and Prior, 1999; Gillespie et al., 2007; Prior et al., 2005). The ORAC value of LMP from JHLB significantly increased in a dose-dependent manner (Fig. 5). Similar results were reported by Kim et al. (2013) who found that the ORAC activity of pig skin gelatin hydrolysates increased with dose, and $1 \mathrm{mg} / \mathrm{mL}$ of pig skin gelatin hydrolysates had $141.39 \mu \mathrm{M} \mathrm{TE} / \mathrm{g}$ of ORAC activity. In this study, the ORAC value of low molecular weight peptides from JHLB at a concentration of $1 \mathrm{mg} / \mathrm{mL}$ was $101.85 \mu \mathrm{M}$ TE, which was lower than the ORAC value for pig skin gelatin hydrolysates. However, Kim et al. (2013) stated that the ORAC values of horse leg bone hydrolysates of less than $3 \mathrm{kDa}$ produced with pepsin, or multifect, or pepsin+pancreatin were 0.12 , 0.20 , and $0.17 \mathrm{mM} \mathrm{TE} / \mathrm{g}$, respectively.

Experimental studies and clinical trials investigating the effects of oral supplementation with vitamins, polyphenols, micronutrients, and proteins have indicated that dietary compounds can modulate skin function (Zague et al., 2011). Moreover, the photoprotective potential of antioxidant intake has been the subject of a considerable number of studies (Chiu et al., 2005; Heinrich et al., 2006). In this study, we did not evaluate the oral supplementation effect of LMP-JHBH on photoprotective potential. However, our data suggest that LMP-JHLB could have antiwrinkle effects due to its antioxidant activity.

\section{Anti-wrinkle and cytotoxic activity of low molecu- lar weight hydrolysates of JHLB}

Collagenase inhibition activity

It is well known that the major cause of skin wrinkling 


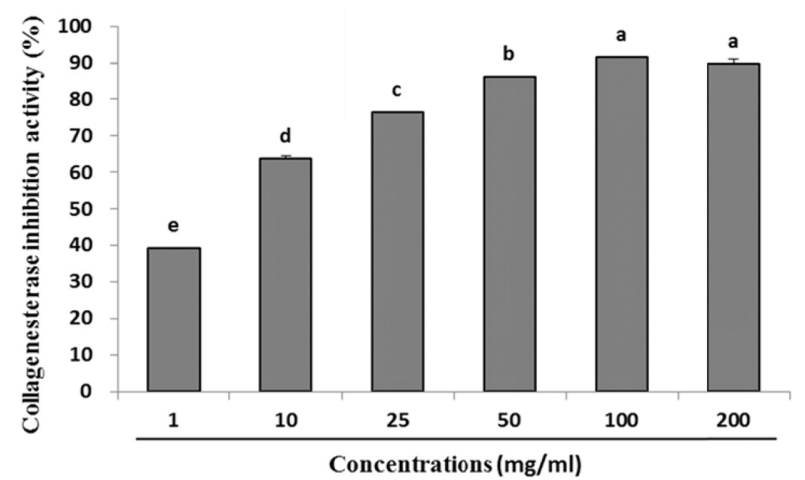

Fig. 7. Collagenase inhibition activity (\%) of LMP from JHLB hydrolysates with pancreatin.

is due to collagen fiber deficiencies in aged and photoaged human skin. The collagenase inhibition activity of low molecular weight peptides from JBLH is shown in Fig. 7. Collagenase inhibition activity of the hydrolysates at $1,10,25,50$, and $100 \mathrm{mg} / \mathrm{mL}$ significantly increased in a dose dependent manner. This result is supported by the findings of Zagu et al. (2011) who reported that daily ingestion of collagen hydrolysates for 4 wk could increase type I and type IV collagen biosynthesis in rats. The most important sources for gelatin and collagen hydrolysate production are bovine hides and bone and pig skin. In this study, we used horse leg bone to generate gelatin extracts and pancreatin to hydrolyze the water soluble bone gelatin to obtain low molecular weight collagen hydrolysates of less than $3 \mathrm{kDa}$. Zague et al. (2011) reported that it is likely that the biological activity of oral collagen hydrolysates in skin could be achieved, at least partly, by ProHyp (which is the major peptide in human plasma after oral ingestion of any type of collagen hydrolysate), which may act as a biological messenger triggering the synthesis of new collagen fibers and extracellular matrix recognition by stimulating fibroblasts.

\section{Elastase inhibition activity}

The elastase inhibition activity of the low molecular weight peptides from JHLB is shown in Fig. 6. As a positive control, ursolic acid at $100 \mu \mathrm{g} / \mathrm{mL}$ was used and showed approximately $37 \%$ elastase inhibition activity. The low molecular weight peptides from JHLB at 25, 50, 100 , and $200 \mathrm{mg} / \mathrm{mL}$ had increased elastase inhibition activity in a dose dependent manner $(p<0.05)$. Eighty percent of the dry weight of skin is collagen, which is responsible for the tensile strength of the skin (Thring et al., 2009). Skin elasticity is attributable to its unique elastic recoil properties and the elastin fiber network that makes

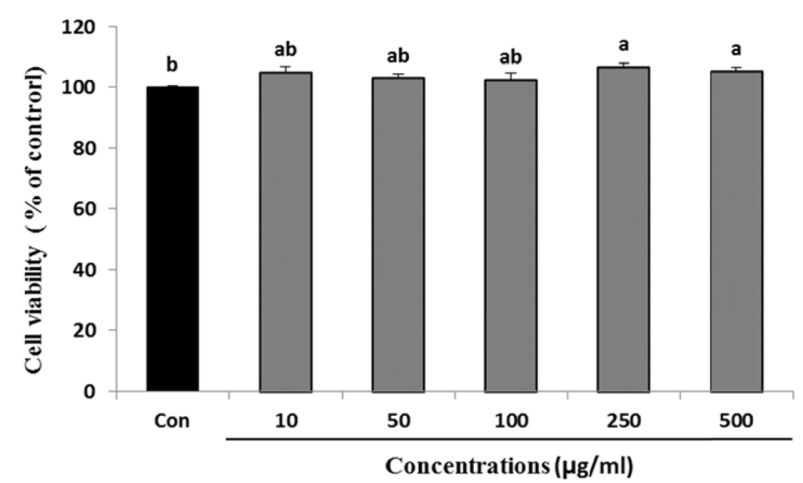

Fig. 8. Effect of LMP from JHLB extracts by pancreatin on human fibroblast cell viability.

up $2-4 \%$ of the extracellular matrix along with glycoaminoglycans that are involved in hydration of the skin (Jenkins, 2002). Elastin fibers are produced by fibroblasts and are primarily affected by photoageing, which results in visible changes in the skin such as wrinkles, pigmentation and changes in skin thickness (Jeong et al., 2011; Thring et al., 2009).

\section{Cell cytotoxicity and ultraviolet irradiation}

Cell viability of human fibroblasts after treatment with low molecular weight JHLB at various concentrations $(10,50,100,250$, and $500 \mu \mathrm{g} / \mathrm{mL})$ is shown in Fig. 8. Cell viability of fibroblasts treated with low molecular weight JHLB at 10,50 , and $100 \mu \mathrm{g} / \mathrm{mL}$ had no significant difference in viability compared to untreated cells. However, low molecular weight JHLB at 250 and $500 \mu \mathrm{g} / \mathrm{mL}$ resulted in significantly higher cell viability compared with the untreated control group. MTT assays were used to measure cell cytoxicity and the results indicated that low molecular weight JHLB had no cell cytoxicity.

Comparison of human fibroblast cell morphology after treatment with UVB irradiation and low molecular weight hydrolysates of JHLB is shown in Fig. 9A. Human fibroblast cells without UVB irradiation and low molecular weight JHLB in control cultures had a normal morphology, however, the morphology changed significantly after UVB irradiation compared to unirradiated control cells. Kim et al. (2011) showed that oral supplementation of collagen peptides (Gly-Pro-Hydroxyprolin, molecular weight $1.5 \mathrm{kDa}$ ) to hairless mice when exposed to UVB irradiation protected the skin from wrinkles. MTT assays were carried out to determine cell viability of the fibroblasts and showed that UVB irradiation significantly decreased cell viability up to $50 \%(p<0.05)$. Treatment with low molecular weight JHLB at 10,50 , and $100 \mu \mathrm{g} / \mathrm{mL}$ had no 


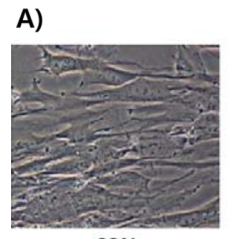

CON

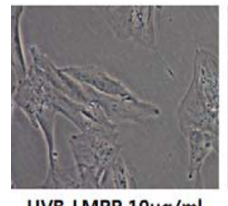

UVB-LMPP $10 \mu \mathrm{g} / \mathrm{ml}$

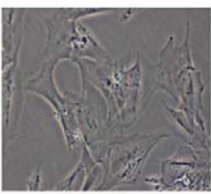

UVB-CON

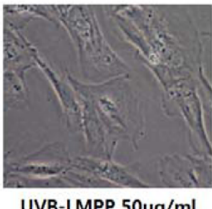

UVB-LMPP $50 \mu \mathrm{g} / \mathrm{ml}$

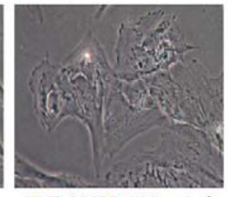

UVB-LMPP $100 \mu \mathrm{g} / \mathrm{ml}$

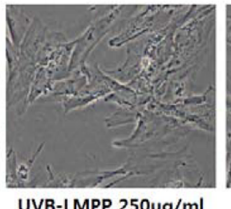

UVB-LMPP $250 \mu \mathrm{g} / \mathrm{ml}$

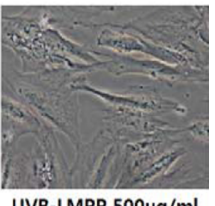

UVB-LMPP 500 $\mu \mathrm{g} / \mathrm{ml}$

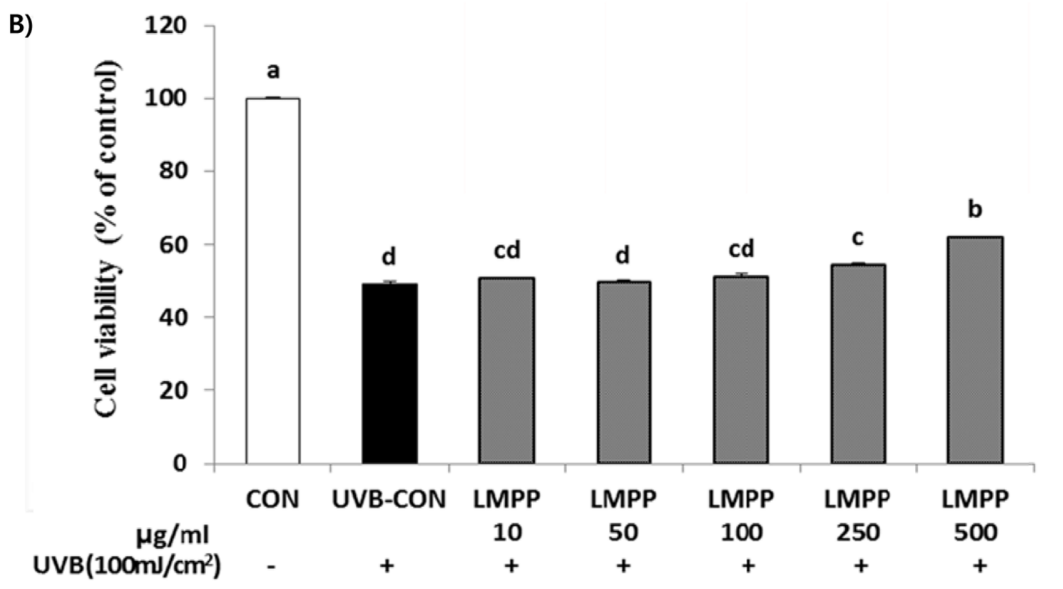

Fig. 9. Effect of LMPfrom Jeju horse leg bone extracts by pancreatin on cell viability. A), human fibroblast cell morphology; B), human fibroblast cell viability change after UV irradiation and LMP-JHLB.

protective effect for cell viability after UVB irradiation. However, treatment with low molecular weight JHLB at 250 and $500 \mu \mathrm{g} / \mathrm{mL}$ resulted in significantly higher cell viability after UVB irradiation compared with untreated control cells (Fig. 9B). These results show that the LMP from JHLB has the potential to be used as an anti-oxidant and anti-wrinkle compound in the food industry. In vivo testing should be carried out to further characterize the potential benefit of LMP from JHLB as a dietary supplement to prevent skin aging.

\section{Acknowledgements}

This work was carried out with the support of the "Cooperative Research Program for Agriculture Science \& Technology Development (Project No. PJ009417)" Rural Development Administration, Republic of Korea.

\section{References}

1. Alvarez-Suarez, J. M., Giampieri, F., Gonzalez-Paramas, A. M., Damiani, E., Astolfi, P., Martinez-Sanchez, G., Bompadre,
S., Quiles, J. L., Santos-Buelga, C., and Battino, M. (2012) Phenolics from monofloral honeys protect human erythrocyte membranes against oxidative damage. Food Chem. Toxicol. 50, 1508-1516.

2. Benzie, I. F. and Strain, J. J. (1996) The ferric reducing ability of plasma (FRAP) as a measure of "antioxidant power": The FRAP assay. Anal. Biochem. 239, 70-76.

3. Blois, M. S. (1958) Antioxidant determination by the use of a stable free radical. Nature 181, 1199-1200.

4. Cannell, R. J. P., Kellan, S. J., Owsianks, A. M., Walker, J. M. (1988) Results of a large scale scrren of microalgae for the production of protease inhibitors. Planta Med. 54, 10-14.

5. Cao, G. and Prior, R. L. (1999) Measurement of oxygen radical absorbance capacity in biological samples. Methods Enzymol. 299, 50-62.

6. Cheon, S. J., Jang, M. J., Jang, Y. A., Choi, E. Y., Jun, D. H., Kim, Y. H., Cho, W. A., Jeong, Y. S., Kwon, H, B., Kim, T. H., Choi, K. L., Do, J. R., Lee, C. E. and Lee J. T. (2008) Antiwrinkle effect of cambodian Phellinus linteus extracts. J. Life Sci. 18, 1718-1722.

7. Chiu, A. E., Chan, J. L., Kern, D. G., Kohler, S., Rehmus, W. E., and Kimball, A. B. (2005) Double-blinded, placebocontrolled trial of green tea extracts in the clinical and histological appearance of photoaging skin. Dermatol. Surg. 31, 855859. 
8. Farage, M. A., Miller, K. W., Elsner, P., and Maibach, H. I. (2008) Intrinsic and extrinsic factors in skin ageing: a review. Inter. J. Cosmetic Sci. 30, 87-95.

9. Gillespie, K. M., Chae, J. M., and Ainsworth, E. A. (2007) Rapid measurement of total antioxidant capacity in plants. Nature Protocols 2, 867-870.

10. Han, J. H., Kim, M. R., Park, Y., Hong, Y. H., and Suh, H. J. (2013) Skin permeability of porcine placenta extracts and its physiological activities. Korean J. Food Sci. An. 33, 356-362.

11. Heinrich, U., Tronnier, H., Stahl, W., Béjot, M., and Maurette, J. M. (2006) Antioxidant supplements improve parameters related to skin structure in humans. Skin Pharmacol. Physiol. 19, 224-231.

12. Jenkins, G. (2002) Molecular mechanisms of skin ageing. Mech. Ageing Dev. 123, 801-810.

13. Jeon, H. S., Seo, J. E., Kim, M. S., Kang, M. H., Oh, D. H., Jeon, S. O., Jeong, S. H., Choi, Y. W., and Lee, S. (2013) A retinyl palmitate-loaded solid lipid nanoparticle system: Effect of surface modification with dicetyl phosphate on skin permeation in vitro and anti-wrinkle effect in vivo. Inter. J. Pharmaceu. 452, 311-320.

14. Jeong, H. R., Kim, J. H., Jo, Y. N., Jeong, J. H., and Heo, H. J. (2011) Characterization as cosmetic substances of chestnut inner skin extracts with antioxidant activity. J. Agric. Life Sci. 45, 183-191.

15. Kim, D., Pak J. I., Chae, H., Kim, Y. B., and Jang, A. R. (2013) Antioxidation effect of leg bone extracts and enzyme hydroltysates from Jeju cross bred horses (Jeju native horse * Thoroughbred). J. Life Sci. 23, 1147-1154.

16. Kim, J. H., Cho, S. H., Seong, P. N., Hah, K. H., Jeong, J. H., Lim, D. G., Park, B. Y., Lee, J. M., Kim, D. H., and Ahn, C. N. (2007). Effect of maturity scores and number of extractions on the chemical properties of water extract from Hanwoo shank bones. Korean J. Food Sci. An. 27, 463-468.
17. Kim, J. K., Lee, J. H., Bae, I. H., Seo, D. B., and Lee, S. J. (2011). Beneficial effect of a collagen peptide supplement on the epidermal skin barrier. Korean J. Food Sci. Technol. 43, 458-463.

18. Masaki, H. (2010) Role of antioxidants in the skin: anti-aging effects. J. Dermatol Sci. 58, 85-90.

19. Park, S. S., Lee, H. J., Yoon, W. J., Kang, G. J., Yang, E. J., Kim, H. S., Choo, C. S., Kang, H. K., and Yoo, E. S. (2010). Effects of horse bone extracts on the induced postmenopausal osteoporosis in rats. Kor. J. Pharmacogn. 41, 204-209.

20. Prior, R. L., Wu, X., and Schaich, K. (2005) Standardized methods for the determination of antioxidant capacity and phenolics in foods and dietary supplements. J Agric Food Chem. 18; 53(10), 4290-4302.

21. Re, R., Pellegrini, N., Proteggente, A., Pannala, A., Yang, M., and Rice-Evans, C. (1999) Antioxidant activity applying and improved ABTS radical action decolorization assay. Free. Radical. Biol. Med. 26, 1231-123.

22. Siebecker, A. (2005). Traditional bone broth in modern health and disease. Available from: http://www.townsendletter.com/ FebMarch2005/broth0205.htm. Accessed Aug. 20, 2014.

23. Thring, T. S. A., Hili, P., and Naughton, D. P. (2009) Anti-collagenase, anti-elastase and anti-oxidant activities of extracts from 21 plants. BMC Complementary and Alternative Medicine 9, 27.

24. Uitto, J. and Bernstein, E. F. (1998). Molecular mechanisms of cutaneous aging: connective tissue alterations in the dermis. J. Investig. Dermatol. Symp. Proc. 3, 41-44.

25. Zague, V., de Freitas, V., da Costa Rosa, M., de Castro, G. A., Jaeger, R. G., and Machado-Santelli, G. M. (2011). Collagen hydrolysate intake increases skin collagen expression and suppresses matrix metalloproteinase 2 activity. J. Med. Food 14, 618-624.

(Received 2014.8.30/Revised 2014.11.8/Accepted 2014.11.16) 